\title{
CREATION OF A CELL-BASED DIGITAL CADASTRAL MAPPING SYSTEM (DIGITAL CADASTRE): A CASE STUDY OF GOSHEN BEACH ESTATE, LEKKI PENINSULA, VICTORIA ISLAND
}

\author{
${ }^{1}$ Olusina J. O., ${ }^{2}$ Olaleye J. B., ${ }^{3}$ Alademomi A.S. and ${ }^{4}$ Ojie T. I. \\ Department of Surveying \& Geoinformatics, University of Lagos, Lagos, Nigeria. \\ 1joolusina1@yahoo.com; 리 ola@yahoo.com; ${ }^{3}$ geomfred@yahoo.com
}

\begin{abstract}
The analogue ways of land administration over the years in developing countries have brought retrogression to land development and its sustainability as a limited natural resource. The use of pencil and papers in land management is outdated and has reduced efficiency. Fast delivery of land related products from government authorities and the private sector takes weeks or months. The need for transformation from analogue approach (traditional cadastre) into the digital technology era (digital cadastre) in order to derive the seemingly unlimited benefits is pertinent. Digital cadastre enhances land transaction activities to be conducted in a business manner. Similarly, land subdivision or boundary redefinition, land registration and land marketing are achieved with better accuracy. This paper discusses the need to introduce a national Cell-Based Digital Cadastral Mapping System model (DCMS) that spans from the federal level down to the states, local governments and the private enterprises such as estate surveying firms. That is, from geodetic accuracy to tertiary (micro) accuracy in order to achieve a seamless nationwide digital cadastre coverage. At the micro level of creating DCMS, Goshen Beach Estate in Lekki Peninsula was used as a case study. The use of Unique Parcel Identifier (UPI) and Spatial Indexing were discussed. Quasi-Land analysis was carried out. From this study, it was discovered that productivity and delivery of land information are enhanced; opportunity of multiple users guides against data and resources duplication; and legal, technical (organizational and technological) and financial issues are better tracked and tackled using DCMS.
\end{abstract}

Keywords: Cadastral, Geographic Information Systems (GIS), Multipurpose Cadastre, Parcel, Topographic Maps.

\section{Introduction}

Digital cadastre provides a means of identifying rules and regulations governing the survey and the detailed description of each parcel. With different government agencies involved in digital cadastre, description of parcels, security of property owners' right, improvement on the efficiency and processes of land management and given access to the public are achievable.

In this era of information technology, the rate of data acquisition, processing and management are on the increase. The central, regional and local government authorities need the availability and use of digital cadastre for several administrative purposes. A Multipurpose Digital Cadastre (MDC) makes land management easier. Administering rules and regulations on rights of individuals and government, based on different jurisdictions, can be achieved through the use of universal and unique parcel identifier (UPI) tied to individual parcels, several administrative documents and databases.

Computerization of parcel information (such as survey plan, right-of-way and utilities) and other map information enables easy information storage, retrieval, manipulation, reduced duplications and display of geographically referenced information. Cadastral information are easily shared by various map users and can produce derived or customized map layers that will meet the need of the users. 
However in Nigeria at various governmental levels (federal, state or local), the creation and use of the digital cadastre is low. Sadly enough, till date some state ministries have not computerized their cadastre process and there are a lot of crises on duplications of titles to same landed property.

In 2009, the Federal Government of Nigeria came up with the Land Reform Programme by setting up a technical committee but up till now, the programme has met some "Nigerian Factor" snag. In actual sense, the use of digital cadastral mapping system (DCMS) should go beyond federal level to state level to local government level and finally to the private sector such as estate management.

This paper actually demonstrates the creation of a Digital Cadastral Mapping System (Digital Cadastre) with Goshen Beach Estate, Lekki Peninsula, Victoria Island as a case study.

\section{Study Area}

The area under study is a private development called 'Goshen Beach Estate'. It is located in Lekki Peninsula, Victoria Island, Lagos State of Nigeria, between latitude $6^{\circ} 25^{\prime} 19.97^{\prime \prime} \mathrm{N}$ to $6^{\circ} 25^{\prime} 31.47^{\prime \prime} \mathrm{N}$ and longitude $3^{\circ} 28^{\prime} 30.97^{\prime \prime} \mathrm{E}$ to $3^{\circ} 28^{\prime} 42.70^{\prime \prime} \mathrm{E}$.

Goshen Beach Estate is a beach front development on the shores of the Atlantic Ocean. It consists of eighty six (86) elegantly built units of mainly four (4), five (5) and six (6) bedroom detached houses, each with a two bedroom boys quarter and gate house (Fig. 1.1 and Fig. 1.2).

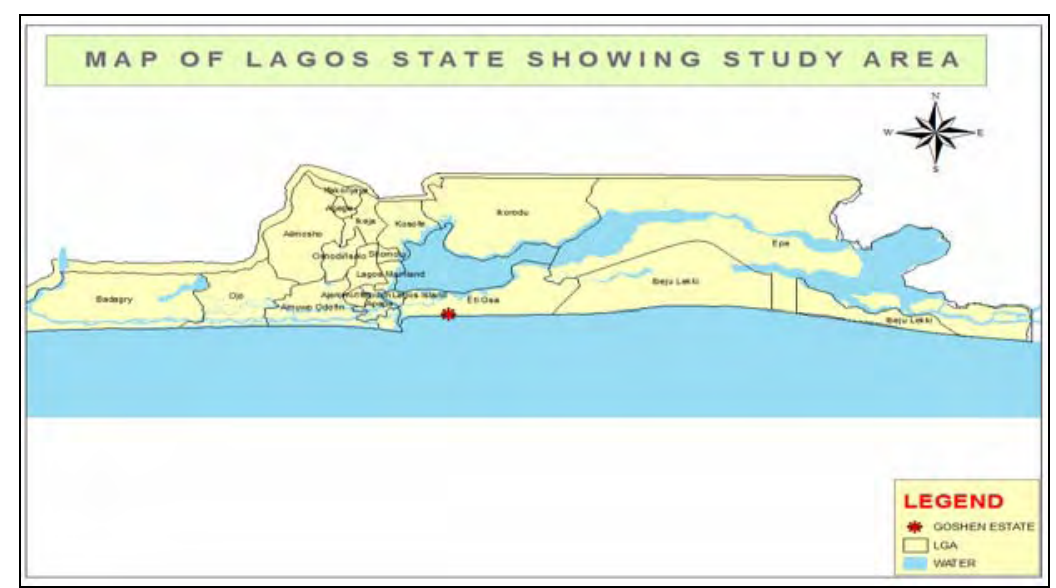

Fig 1.1 Map of Lagos State showing the location of Goshen Beach Estate (Open Stages Incentives, 2009).

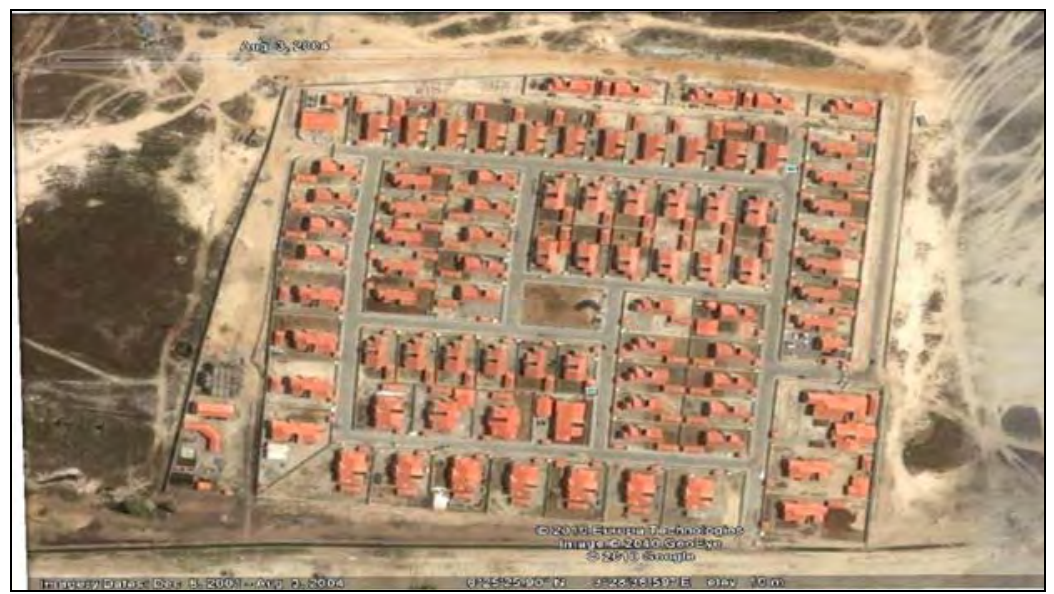

Fig 1.2 Satellite Image of Goshen Beach Estate (Google Earth, 2004) 


\section{Significance of the Study}

Presently land administration in Nigeria has been bedeviled with many problems such as: no adequate record and dissemination of up-to-date information about land ownership, value and use of land and its associated resources; managing land with old techniques; poor acceptance of the concept of Digital Cadastre; lack of agreement concerning standardization on the complexity of spatial data management problems and data sharing; lack of complete multi-purpose national Digital Cadastre for the entire country; and the complexity in spatial data technical integration of stakeholders and the use of Unified and unique Parcel Identifier (UPI).

Digital Cadastre has more advantages than the analogue way of keeping the tracks of information in a land management, because the spatial database is directly linked to the spatial entities on the cadastral map. Land information managed with Digital Cadastre (or DCMS) is more versatile because it can be subjected to many analyses without introducing errors. Such integration can assist in:

1. Enhancement of the process involved in land transfers and exchanges

2. Quick means of assessing revenue generated at any given time

3. Quick decision-making by management on certain policy issues

4. Quick responses to enquiries

5. Updating data on parcels, houses and relevant documents quickly.

Using the creation of DCMS for Goshen Beach Estate as a case study, in the past government used to be the major providers of housing estates in Nigeria, but there is now an increasing wave of private developers involved in housing delivery in order to meet the ever growing daily demand.

The houses built are sold either out-rightly or through mortgage arrangements. Sites and services schemes are also provided and plots of land allocated to individuals to produce their own designs, under strict supervision to meet set standards. Community facilities and general public facilities are provided to make the estates functional (Oluwi, 1994; Eyong, Nwilo \& Orji, 2006).

However, not much effort and management of skills has been put into the management of these estates, for great efficiency and functionality. Among the various aspects of estate management is property management, which involves the application of skill in caring for a property, its surroundings and amenities and also in developing a relationship between landlord and tenant and between tenants.

Most estate managers in Nigeria today use the analogue way of managing properties which has led to a lot of man-hour being wasted by going through voluminous files, improper record keeping and possible double allotment amongst others, hence inefficiency. It is in the light of this that digital cadastre at micro level is being introduced into property management practice. This is to assist in business planning, improving programmes and decision making in various areas of land administration (Oloyede-Kosoko and Alagbe, 2005).

Other benefits that are derivable from application of Digital Cadastre Mapping System (DCMS) include; new and flexible form of output (customized mapping), quick and easy access to large volume of data about the features in the estate, selection of terrain details through answering to some spatial problem, ability to merge one dataset to another and the ability to answer complex land related questions. 
Land as the basis of all societies and fundamental to all aspects of human existence, the Federal Government Land Reform Programme set up in 2009 was given among others the following mandates:

$>$ to collaborate and provide technical assistance to States and Local Governments to undertake land cadastral nationwide

$>$ to ensure that land cadastral boundaries and titles holdings are demarcated in such a way that community, hamlet, village, village area, towns, etc. will be recognizable.

With the Land Reform Programme, the Digital Cadastre Mapping System (DCMS) can be expanded from national to local and enterprise levels.

\section{Fundamentals of a Digital Cadastral Mapping System (DCMS):}

Maps, accompanying records and resources to support mapping and its maintenance are requirements that must be met by any cadastral mapping system, digital or analogue, for property assessment (Olaleye, 1998). The following steps are compulsory:

\section{Needs Analysis}

In creating a new digital cadastral mapping system (DCMS), information must be obtained on: (i) existing cadastral system, and (ii) needs analysis of the new system (Kufoniyi, 1998; Adeoye, 2001). These will assist in taking adequate decisions on issues such as; the type of mapping program to create; technical specifications vis-a-vis technology availability to meet the desired digital cadastral map; fully contracted or fully in-house or partially contracted work; funds needed and available and pilot project plan to test and indentify the possibility of success at national level.

\section{Assembling Source Data}

To create a cadastral map layer, there is need to acquire information on: records of existing surveyed parcel plans, taxing zoning map, geodetic control network, type of ownership and other legal documents, utilities available, right-of-way, road map and so on (Fig. 2.1).

\section{Problem Resolution}

Problems on boundary conflicts must involve, the appraiser, the planning department, attorneys, the owner and his neighbours and other claimants. Taking decision on such conflict boundaries should be carefully adjudge and could be based on documents available, more than verbal claims of people; survey technique adopted during the initial survey; existing laws and regulations on land and mineral boundaries; subdivision rules and software capabilities and their shortcomings (Hardie \& Parks, 1994; Lawal, 1997). All evidences including verbal must be documented and well referenced using the unique parcel identifier (UPI).

To achieve proper assessment of landed properties, the following basics must be available:

National Geodetic Control Network- to ensure accurate, seamless and nationwide mapping coverage. This will be broken down to secondary and tertiary orders in the states and local governments (Fig. 3.4a-c); 
$>$ Base Map Layers- these must be tied to the national geodetic control network and must show major physical features such as roads, contours, rivers and other water bodies, buildings and so on. Existing topographic maps should suffice.

$>$ Imagery- imageries, satellite or aerial photographs, always contain more information than any produced map. Therefore, accurate imageries should be added to the digital mapping system in order to provide more detailed information of the environment and must be tied to the national geodetic control network and the base map.

> Cadastral Map Layers- these should show all existing parcels in the jurisdiction. Since there is no room for gaps and overlaps in cadastral mapping system, therefore accurate seamless cadastral mapping is required. Each parcel in the system must be attributed with the unique parcel identifier (UPI).

> Other Additional Map Layers- in addition to the layers above, other map layers such as street map, utility maps, geological map, hospital locations, schools, government office locations, and so on must be added (Fig. 2.1). Apart from surveyors these are necessary for other digital cadastral map users.

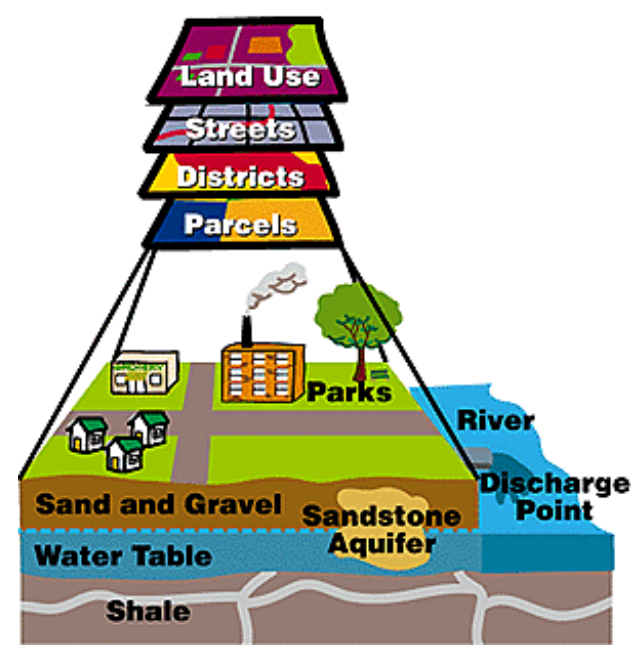

Fig, 2.1 Layers of Digital Cadastral Mapping System (DCMS). Buckley (1997).

> Unique Parcel Identifiers (UPI) - a link must be established between each parcel and the relevant documents (e.g. ownership, value, use, and zoning) through the use of unique identification number or code that is universal in nature (i.e. nationwide). Proper indexing (Fig. 3.4a-c) creates the ability to track details on parcel-document relationship and to a common index for all property records.

$>$ Ownership Information- this includes past ownership records, present ownership status and claims. These details must be properly indexed using the UPI.

$>$ Various Map Products - map products should be made available to various users in different formats such as CD-Rom, DVD, Flash drive, internet, intranet and also hard copy.

> Digital Cadastral Mapping System Program Management- the roles of all the stakeholders in the programme and its maintenance must be clearly articulated and understood by all. These should include functions of manager, surveyors, town planners, tax assessors and legal unit. Procedures, Standards, and Records must be established, associated databases must be created and training and system upgrading mechanism must also be put in place. 
$>$ Quality Control - quality control machinery must also be put in place. Achievable accuracy in hardware and software must be known. To avoid conflicts, plotted parcel layers must be tested for spatial accuracy and the attribute database must be properly linked with the parcels.

$>$ Data BackUp - metadata must be created and every data and document must be adequately backup in safe and secured places.

\section{Research Methodology}

This includes the various stages discussed in Section 2.0 in generating the desired product and solution which also involves the fundamental stages of the geographic information systems (GIS).

Spatial and aspatial data sets were acquired and used in this project. Spatial data includes data taken from satellite images (Google Earth of $1 \mathrm{~m}$ resolution) (Lucas \& Janssen, 2000), layout survey plan of the estate (scale 1:500) and Global Positioning System (GPS) of some important points such as road intersections, electric poles, transformers, plots, water pipes, while aspatial data were extracted from tables, list, and texts. Spatial data were georeferenced and digitized (Deby et al., 2000; Burrough, 1991, Buckley, 1997). Also the layout survey plan of the estate was used for cross checking with the digitized map from the images. It was found that the disparity between features vectorized and the one from the layout survey plan was very insignificant $(0.03 \mathrm{~m})$.

Most of the attribute data such as status of the property (whether it is outright purchase, rent or lease), house types, and status of the Certificate of Occupancy (C of $\mathrm{O}$ ) was obtained from the management of Goshen Beach Estate. The attributes such as addresses, use(s), height, and block number were obtained directly from the site (Nwilo, 1998). A Unique Parcel Identifier (UPI) was given to each parcel which was used to identify documents related to each property. Summary of the steps involved in the spatial data creation is shown in Fig. 3.1.

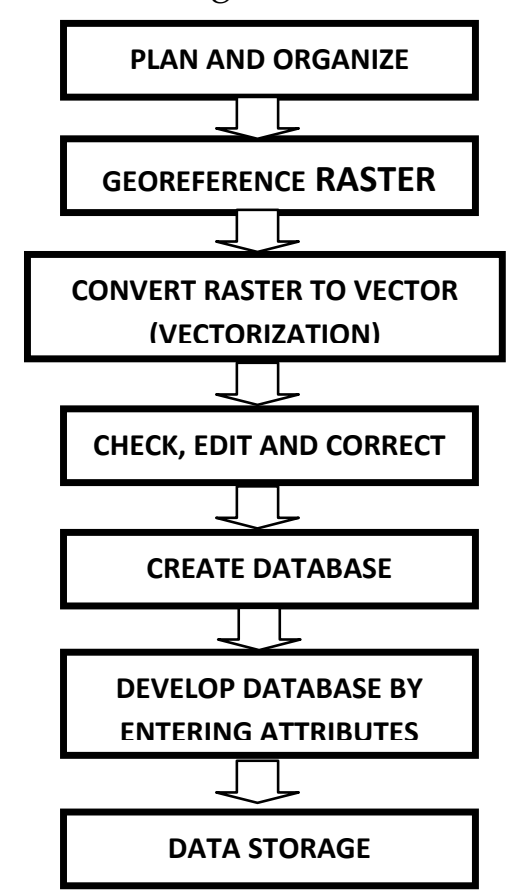

Fig. 3.1 Steps involved in the spatial data creation

ArcGIS 9.2 was used for the creation of Estate Management Information System (EMIS), a GIS-based package. WGS 84 projection was selected under the UTM Zone 31 
Grid, while different shape files (point, line or polygon) in form of map layers were created:

AdministrativeBuilding, BoysQuarters, Clinic, ElectricityLines, ElementarySchool, EstateBoundary, MainGate, MainGate_SecurityPost, ManHoles, Plots, RecreationalGround, ResidentialBuilding, Roads, SecurityPost, SepticTank, SewagePiles, Streets, StreetLights, Transformers, Trees, WaterPipe_4inch, WaterPipe_6inch and WaterPlant.

Features were vectorized and compared with the satellite image (Fig. 3.2).

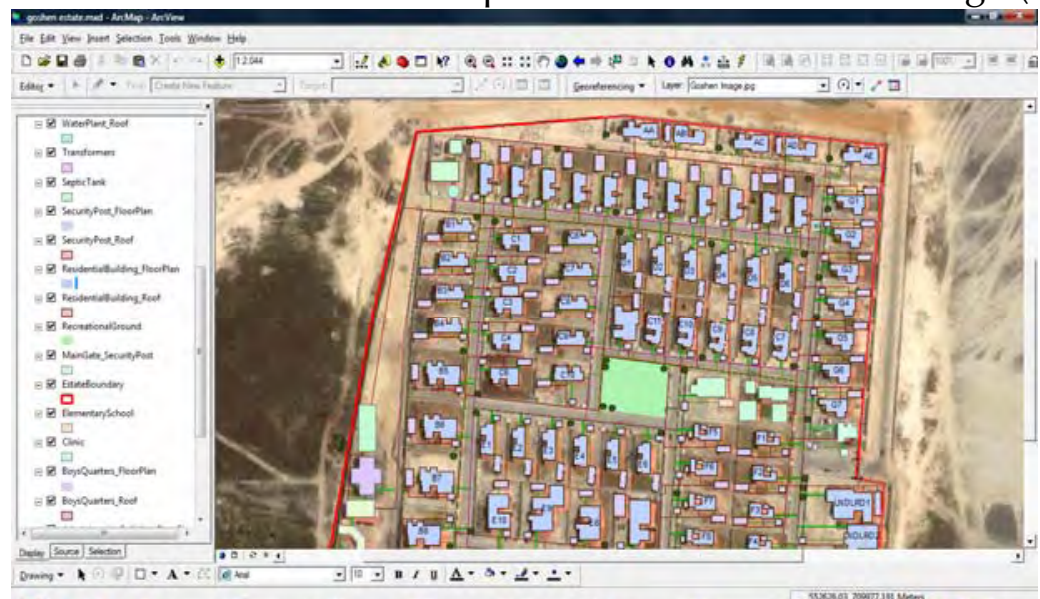

Fig 3.2 Superimposition of Vectorized Features on Satellite Image.

Cartography work was carried out to select appropriate symbols for the polygons, lines and point features vectorized, and allotment of appropriate colours, line thickness and weight for the various entities (Uluocha, 2007) (Fig. 3.3).

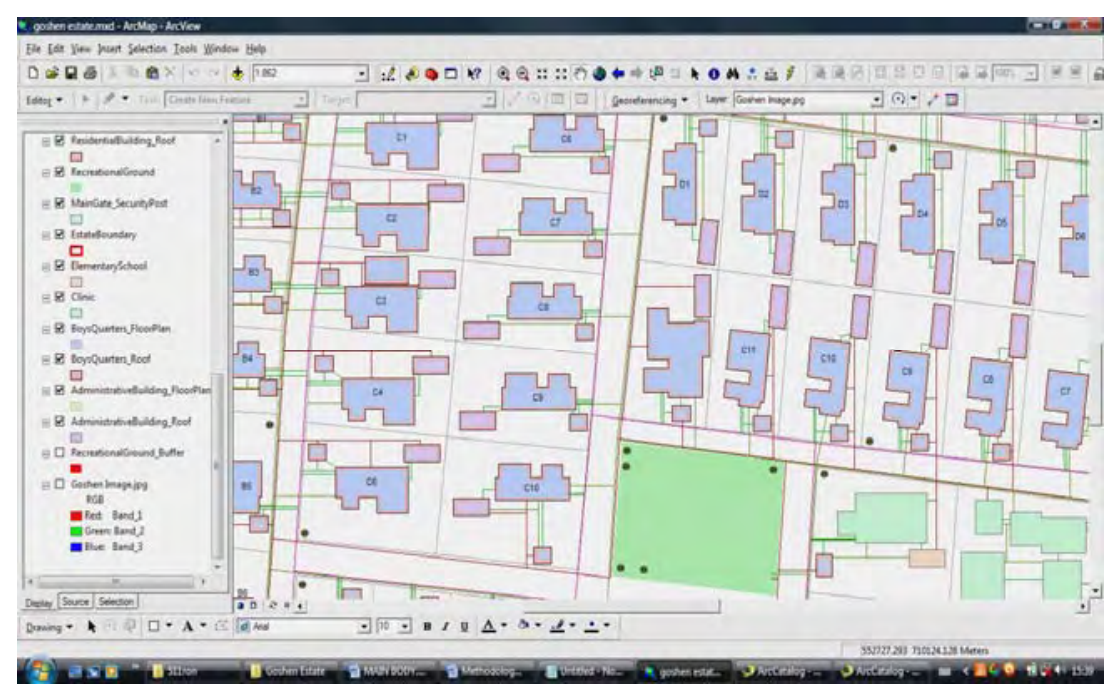

Fig.3.3 Cartographic Visualization of part of the Estate.

\section{Developing the Database}

Database on various attributes (fields) of the various spatial features created include: The fields that were created for 'STREETS' are:

- $\quad$ SID $=$ Street (Feature) Identifier; Shape $=$ Feature type (polyline); Name $=$ Name of the Street; Length = Length of the Street (metres).

The fields that were created for 'PLOTS' are: 
- $\quad$ PID = Plot (Feature) Identifier i.e. Unique Parcel Identifier (UPI); Shape = Feature Type (polygon); SID = Street (Feature) Identifier.

\section{Residential Buildings':}

- $\quad$ BID = Building (Feature) Identifier; Shape = Signifies the feature type (polygons).

Owner = Owner of the Building; Status = Status of the Building (e.g. outright purchase, lease or rent); Blk_No $=$ Block number of the Building; PID = Plot (Feature) Identifier; Type $=$ Type of Building (e.g. 4 bedroom, 5 bedroom or 6 bedroom duplex).

C_of_O = Has Certificate of Occupancy (C. of O.) or not; Area = Area (size) of the building; Perimeter $=$ Perimeter of the building.

For polygonal features such as 'Residential Buildings' and 'Plots', their Areas and Perimeters were calculated automatically using software capability. Similarly, lengths of other polylines features such as 'Streets', 'Roads' and 'Pipelines' were also calculated automatically. The database structure is shown in Table 3.1

\section{Hot Linking Photographs to Vector Data}

Each vectorized feature (mainly buildings) was hyperlinked with digital photographs of the features on each parcel for better visual perception (Fig. 4.11). This can actually be used by estate managers to sell their properties to would-be-buyers online or on stand-alone computer system in their offices instead of taking every customer to the site where the property is located. For all the data acquired and processed, metadata was created.

\section{Spatial Indexing}

Spatial indexing is the proprietary organization of data layers in a horizontal fashion within a GIS. It is utilized in this work by the GIS software to store and retrieve spatial data. Most of the strategies exist for speeding up the spatial feature retrieval process involves partitioning of the geographic area into manageable subsets or tiles. This was adopted in this work. These tiles are then indexed mathematically, e.g. by quadtrees, by $\mathrm{R}$ (rectangle) trees, to allow for quick searching and retrieval when querying is initiated by a user (Fig. 3.4a-c). Spatial indexing is analogous to the definition of map sheets, except that specific indexing techniques are used to access data across map sheet (tile) boundaries.

\section{Cell-Based DCMS Model}

In Hardie and Parks (1994), relationship between homogeneous and heterogeneous lands in relation to land rent was discussed. Homogeneous land is defined as acreage having a fixed bundle of location, topographic, climate and soil characteristics, while heterogeneous land is defined as acreage with variable quantities of these characteristics. A single cash rent prevails for land of homogenous quality, and a welldefined rent schedule $r=r\left(\alpha_{1}, q_{2 ;} \ldots \ldots, \sigma_{N}\right)$. exists for land with different quantities of characteristics $q_{1}, q_{2} \ldots \ldots \ldots, q_{N}$ (the heterogeneous). With suitable definitions of these quantities for the heterogeneous case, $r$ can be continuous and increasing in all arguments. Land quality then can be defined by a single-valued function $q=q_{q}\left(q_{1}, q_{2}, \ldots \ldots, q_{H}\right)$ with $q$ also continuous and increasing in all arguments. 


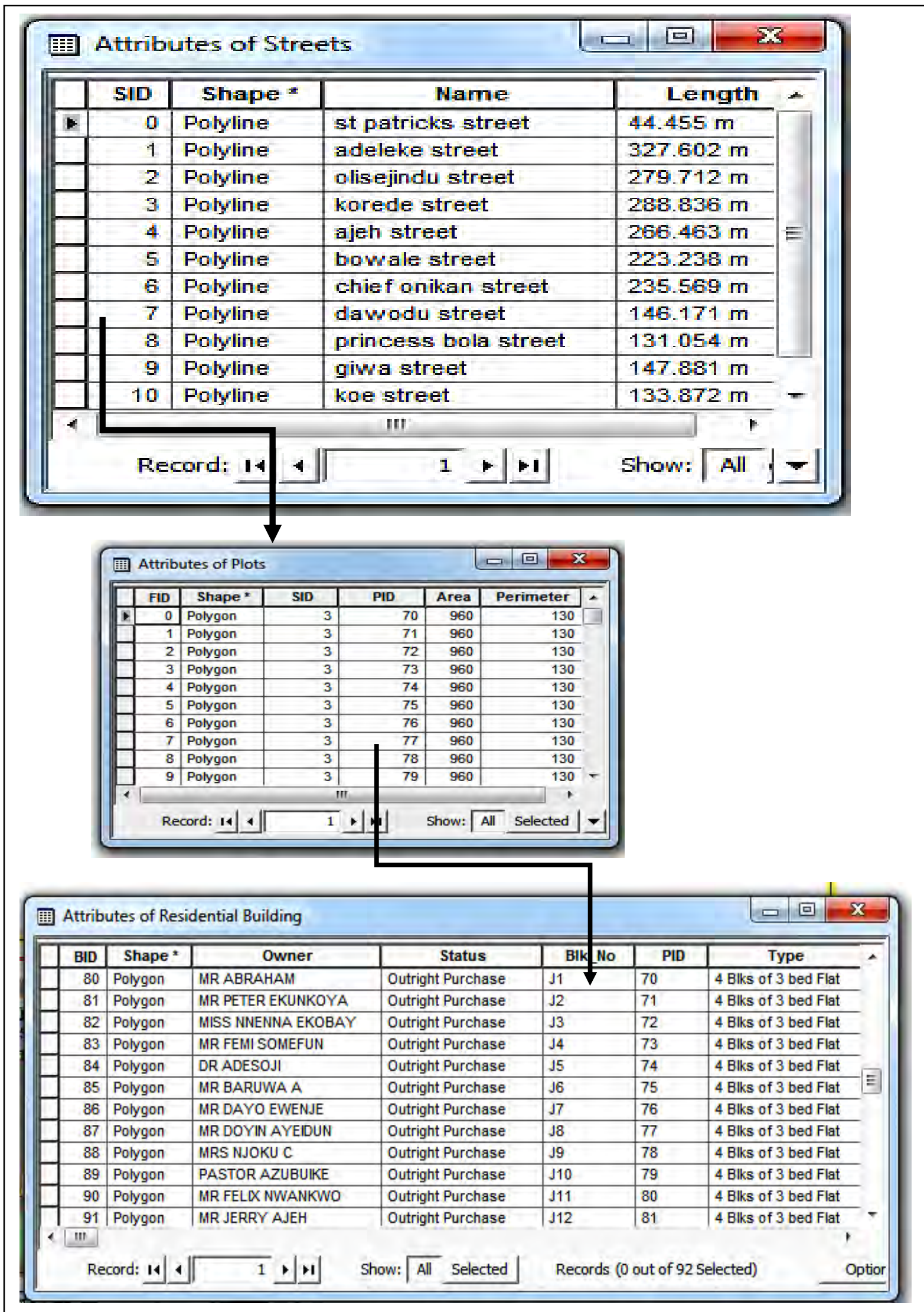

Table 3.1 Database Structure of Goshen Estate. 
Implying that creating a cell-based DCMS model at national level, the location, topographic, climate, land value, soil characteristics, and so on are heterogeneous (variables) over several kilometres (geodetic coverage) whereas within Lekki Peninsula, Victoria Island it could be taken that the state of land is homogeneous (fixed- without variations), plane surface.

For a TOP - DOWN APPROACH to Cell-Based DCMS Model, with heterogeneous characteristics it is based on "whole-to-part" principle (Fig. 3.4a-c). However, some states in the country (Nigeria) like Lagos State have started their state-based DCMS (Ayeni, Kufoniyi \& Akinyede (2003). In order to achieve a seamless DCMS from the state to national level, a DOWN-TOP APPROACH must be adopted (Fig. 3.4c-a). The integration of the DCMS from the individual states must be carried out. Similarly, the individual private estates' DCMS, such as Goshen Beach Estate, must be integrated into state-based DCMS.

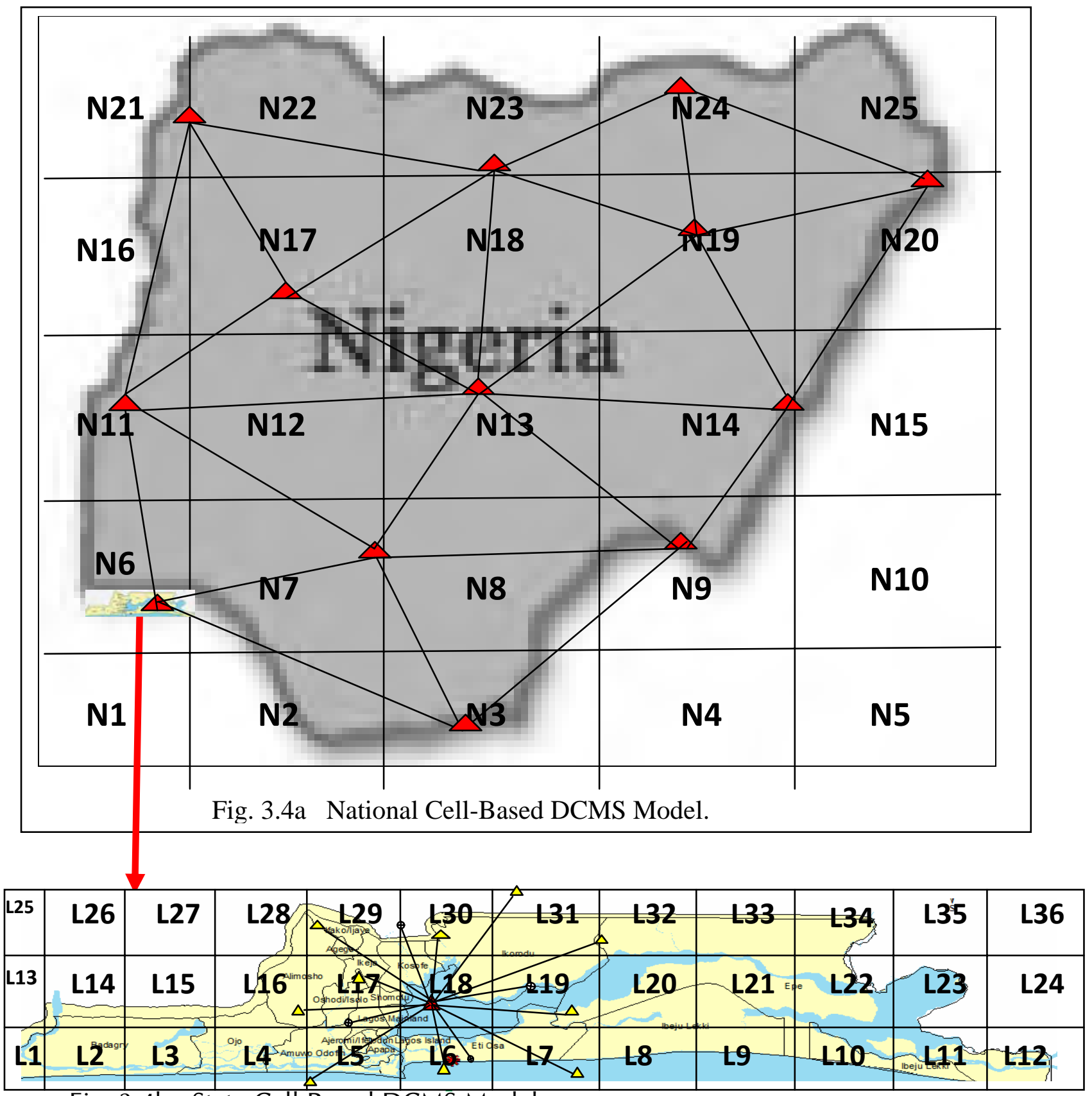

Fig. 3.4b State Cell-Based DCMS় Model. 


\begin{tabular}{|c|c|c|c|}
\hline G1 & G2 & G3 & G4 \\
\hline G5 & G6 & G7 & G8 \\
\hline G9 & G10 & G11 & G12 \\
\hline G13 & G14 & G15 & G16 \\
\hline
\end{tabular}

Fig. 3.4c Micro Cell-Based DCMS Model (e.g. Goshen Beach Estate DCMS).

For a TOP - DOWN APPROACH to Cell-Based DCMS Model, some basic assumptions in the proposed model will include:

1. All cells have the same dimension at each level.

2. Curvature and other necessary corrections are applied at geodetic level

3. Curvature and other major corrections are not applied at tertiary level or micro level cells e.g. within Wards (such as Goshen Beach Estate).

4. Property (land) values vary based on location, development, population, etc.

5. Parcel identifiers are unique to each parcel and unique nationwide i.e. universal unique parcel identifier

6. Municipal or rural tax zoning is based on location.

For a heterogeneous Cell-Based Digital Cadastral Mapping System (DCMS), the equations below are some of the variable quantities (Section 2) that must be determined:

National Geodetic Control Network (Gn) establishment

$G n=f(p, d, m, c, \ldots . . .$.
where: $\quad d=$ distance between pillars
$\quad p=$ number of pillars
$c=$ curvature corrections

Base Map Layers $(B m)$ creation

$B m=f($ topo, $u t, d e, \ldots . . .$.

where: topo $=$ topographic map

$u t=$ various utility maps (such as roads, water pipelines, .......)

de $=$ detailing (such as buildings, streams, footpaths, fence lines, ........)

Cadastral Map Layers $(\mathrm{Cm})$ creation

$\mathrm{Cm}=\mathrm{f}($ par, $b$, dis, brg, $u, \ldots \ldots .$.

where: par $=$ parcel size

$b=$ number of boundary beacons

dis $=$ distance between pillars

$b r g=$ bearing of survey lines

$u n=$ unique parcel identifiers

Additional Map Layers (Am) creation

$A m=f(t, s, z, f, u, \ldots .$.

where: $\quad t=$ municipal and taxing district boundary

$s=$ soil type

$\mathrm{z}=$ zoning

$f=$ flood rate

$u=$ land use/land cover 
Some of the results obtained for a private estate (Goshen Beach Estate) homogenous Cell-Based DCMS are discussed in Section 4.

\section{Queries, Results and Data Analysis}

\section{Queries and Results}

Queries were performed and results were obtained. The various derived or customized maps obtained are shown below.

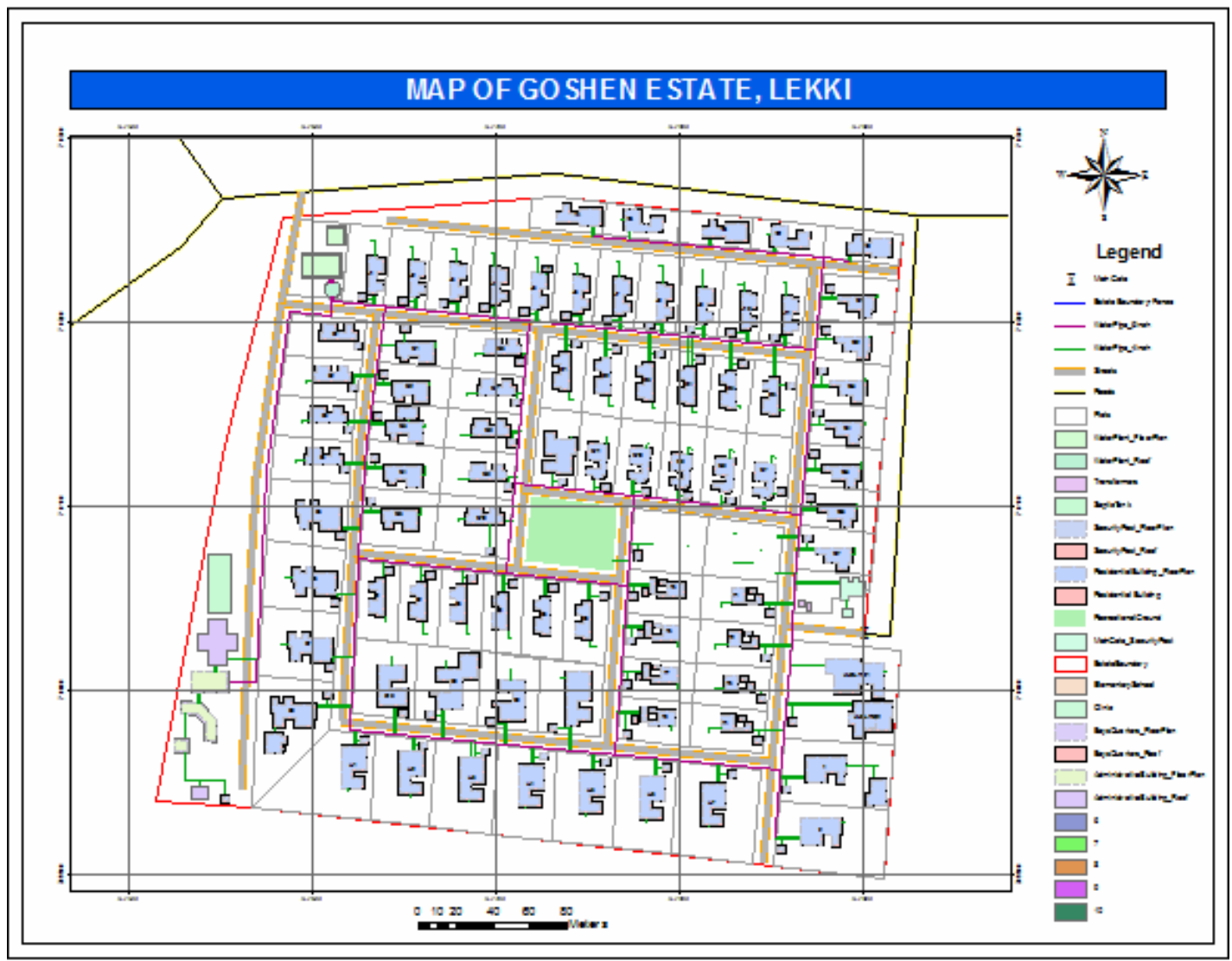

Fig 4.1 Digital map of Goshen Beach Estate

Query 1 - Show the total Estate Polygon and what is the total size of the Estate? 


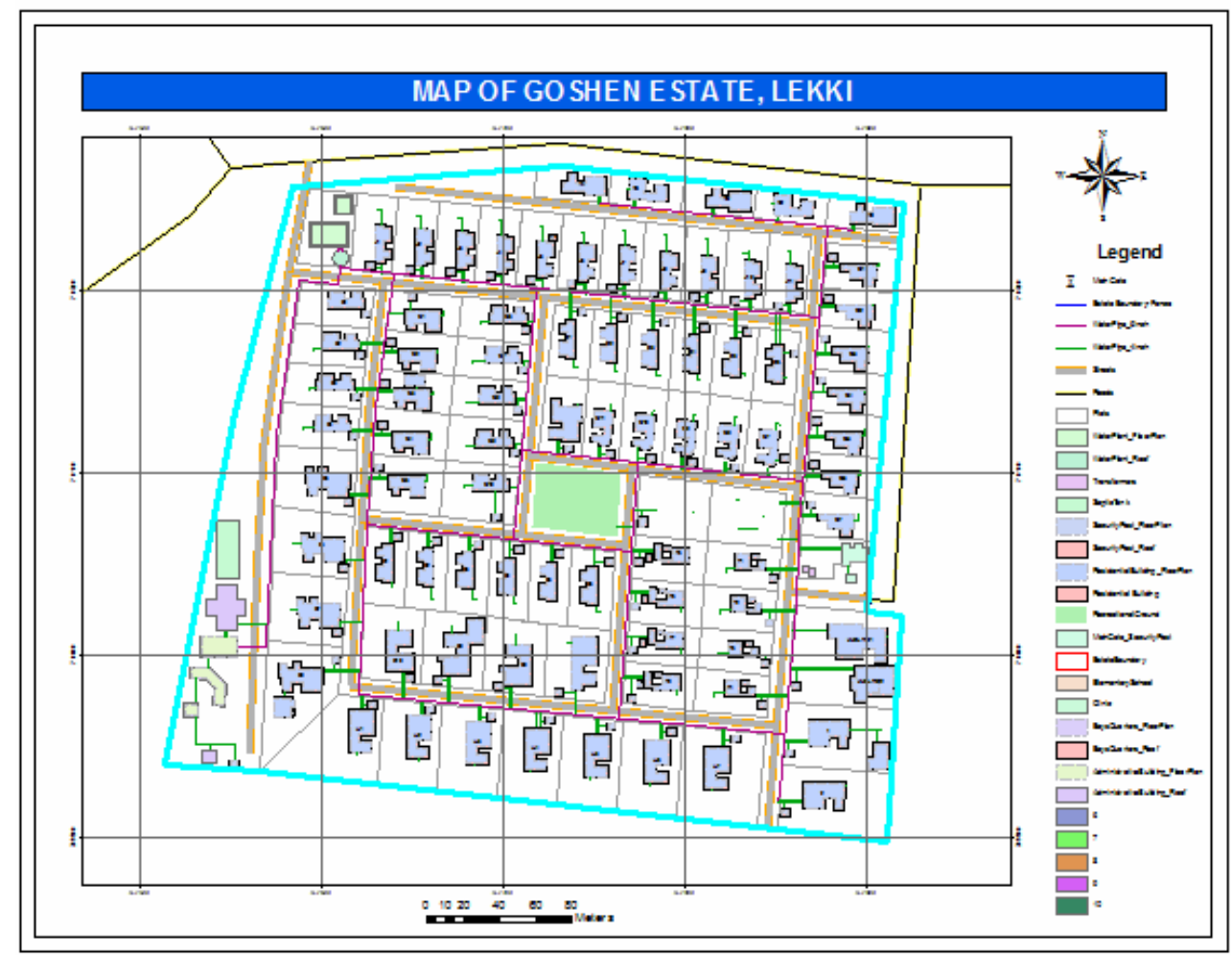

Fig 4.2 A query showing the entire Estate and the total size (Area) $\left[125,056.582 \mathrm{~m}^{2}\right]$

Query 2 - Which buildings are residential blocks within the Estate?

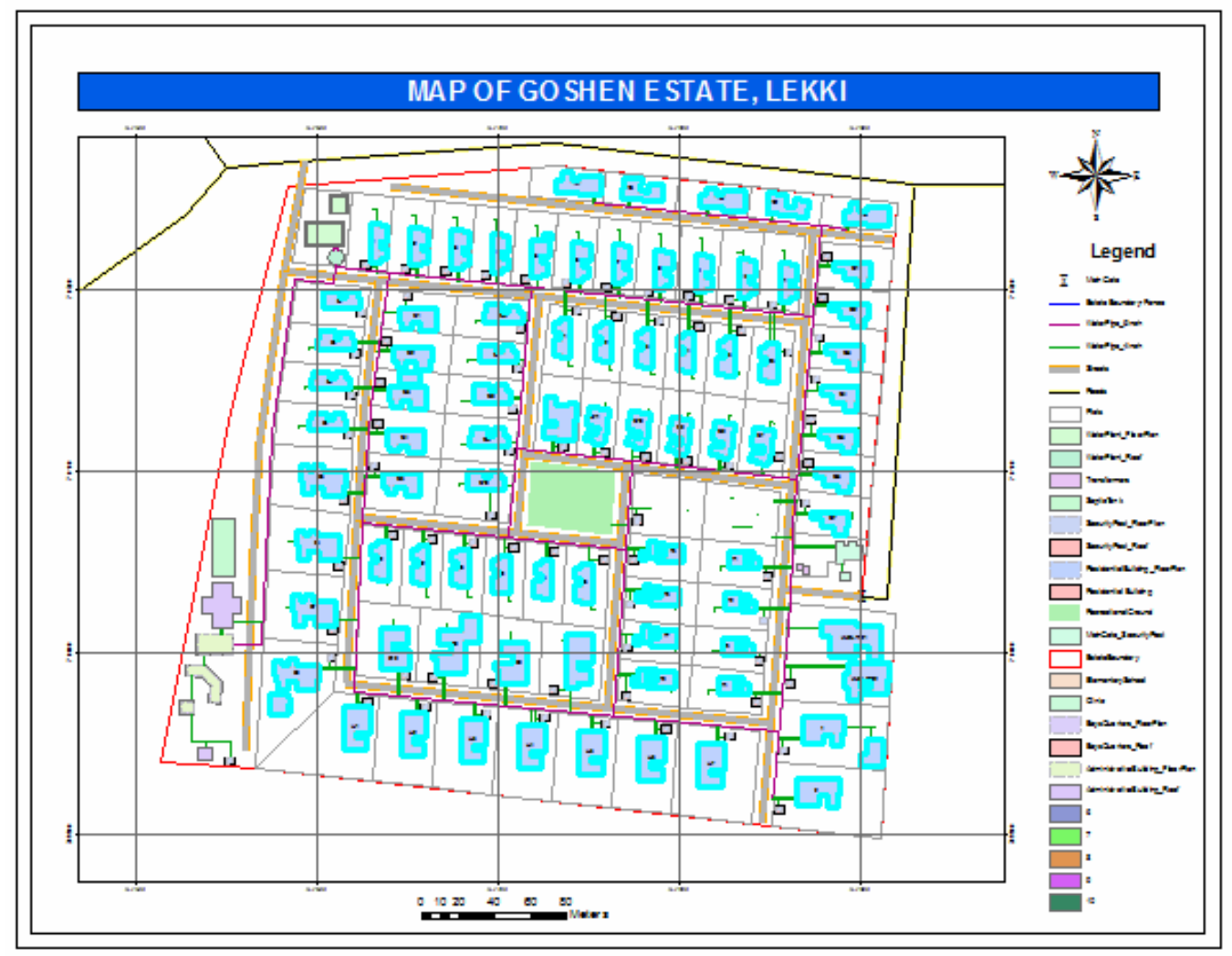

Fig 4.3 A query showing all residential buildings in the estate (86 buildings) 
Query 3 - Which residential buildings are under outright purchase?

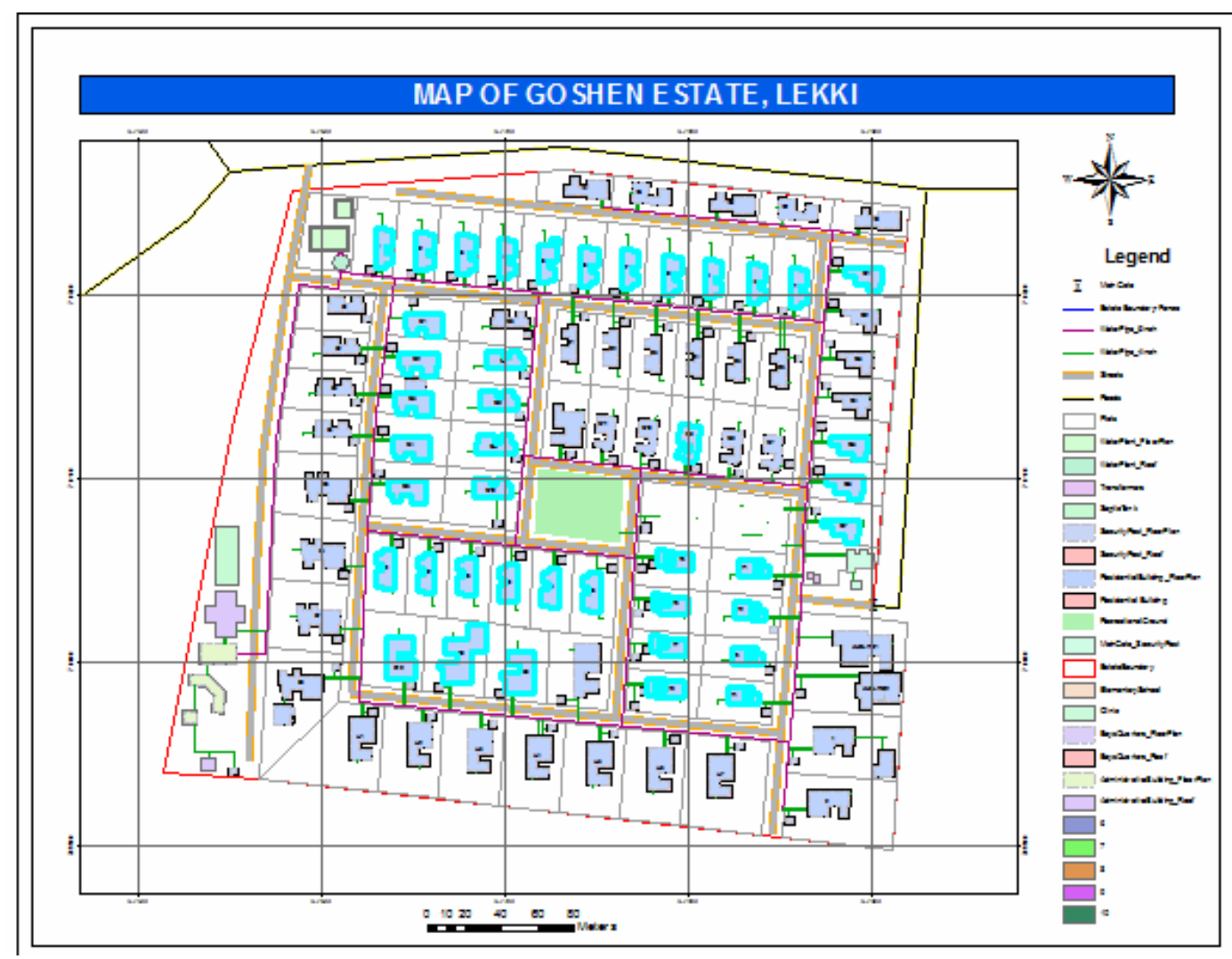

Fig 4.4 A query showing "Residential Buildings under Outright Purchase" (42 buildings)

Query 4 - Which is the biggest plot?

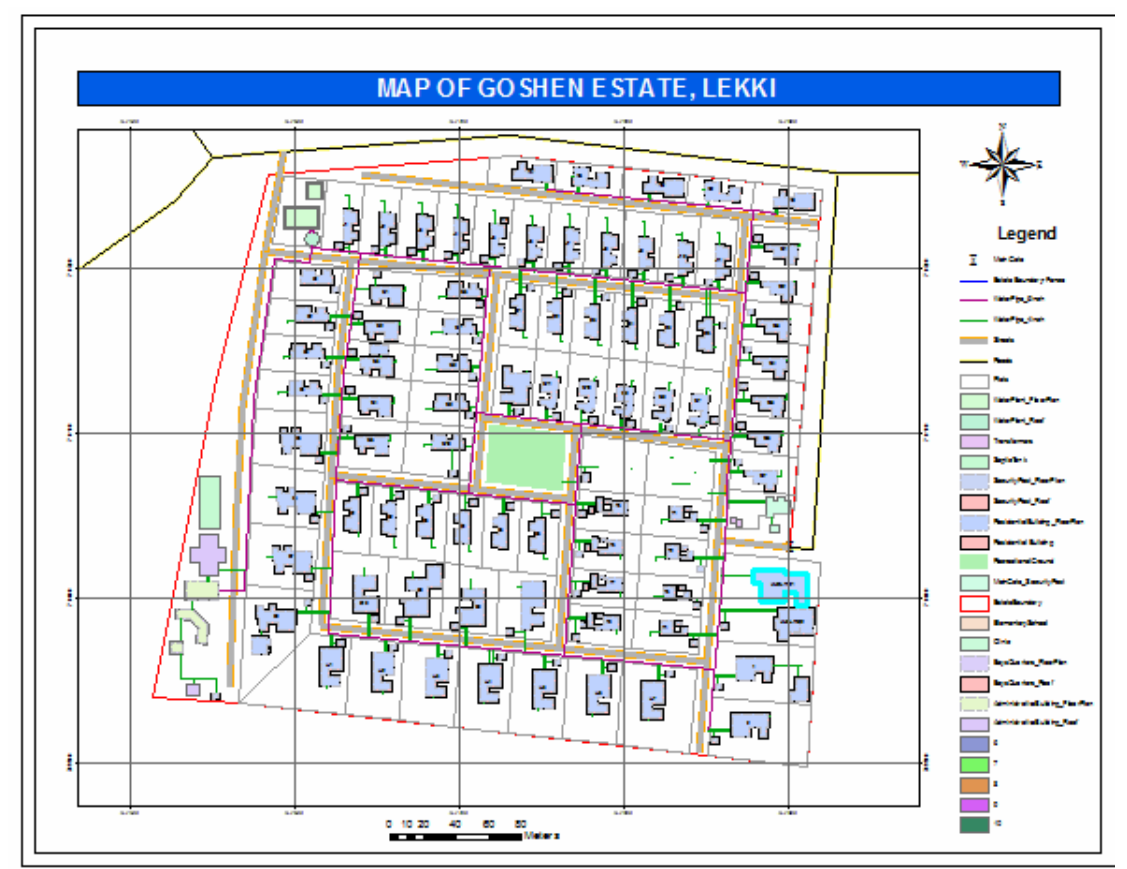

Fig 4.5 A query showing the "Biggest Plot" $\left(3,158 \mathrm{~m}^{2}\right)$

Query 5 - Select the smallest plot. 


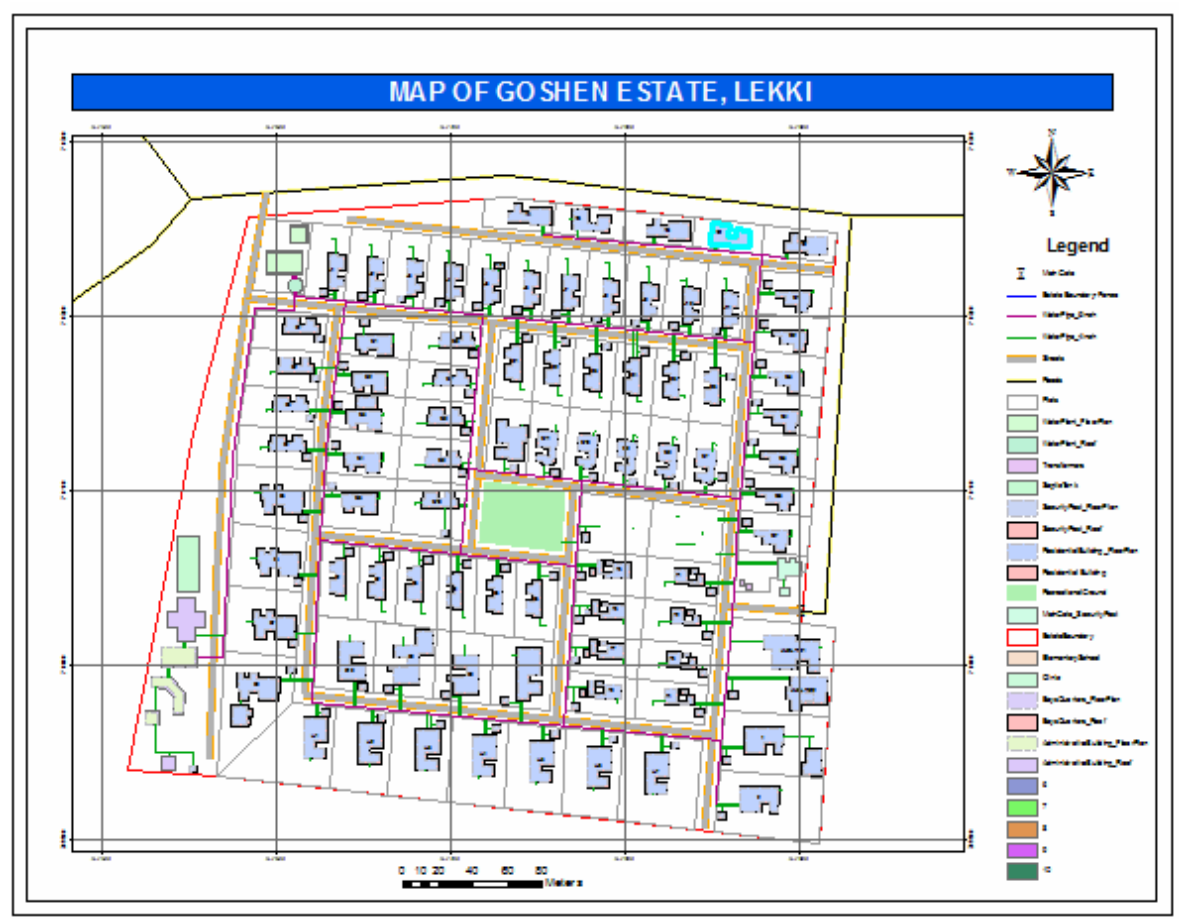

Fig 4.6 A query showing the "Smallest Plot" $\left(676 \mathrm{~m}^{2}\right)$

Query 6 - Which buildings are greater than 250sq.m in floor area?

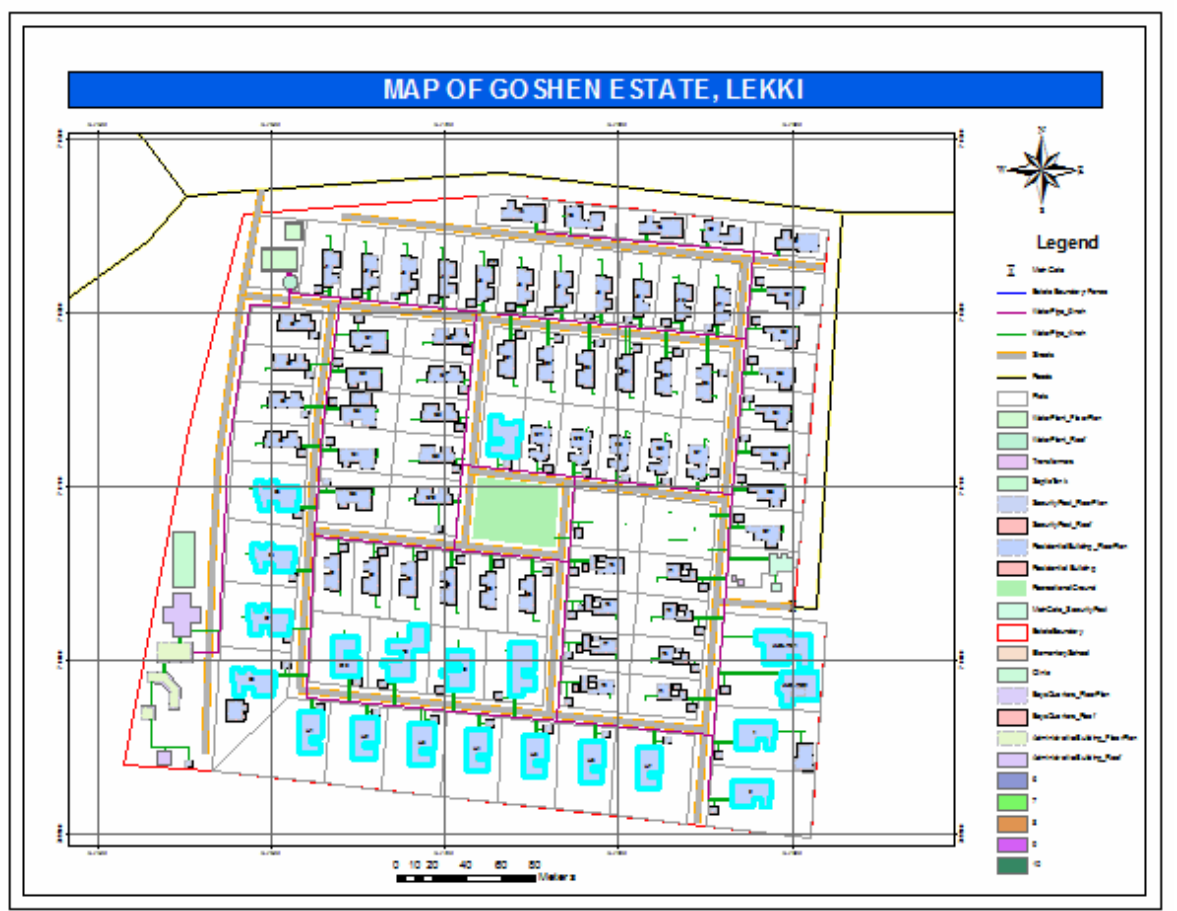

Fig 4.7 A query showing "buidings greater than $250 \mathrm{~m}^{2 \prime}$ (20 buildings) Query 7 - Show all residential buildings that are within $100 \mathrm{~m}$ radius of Recreational Centre? 


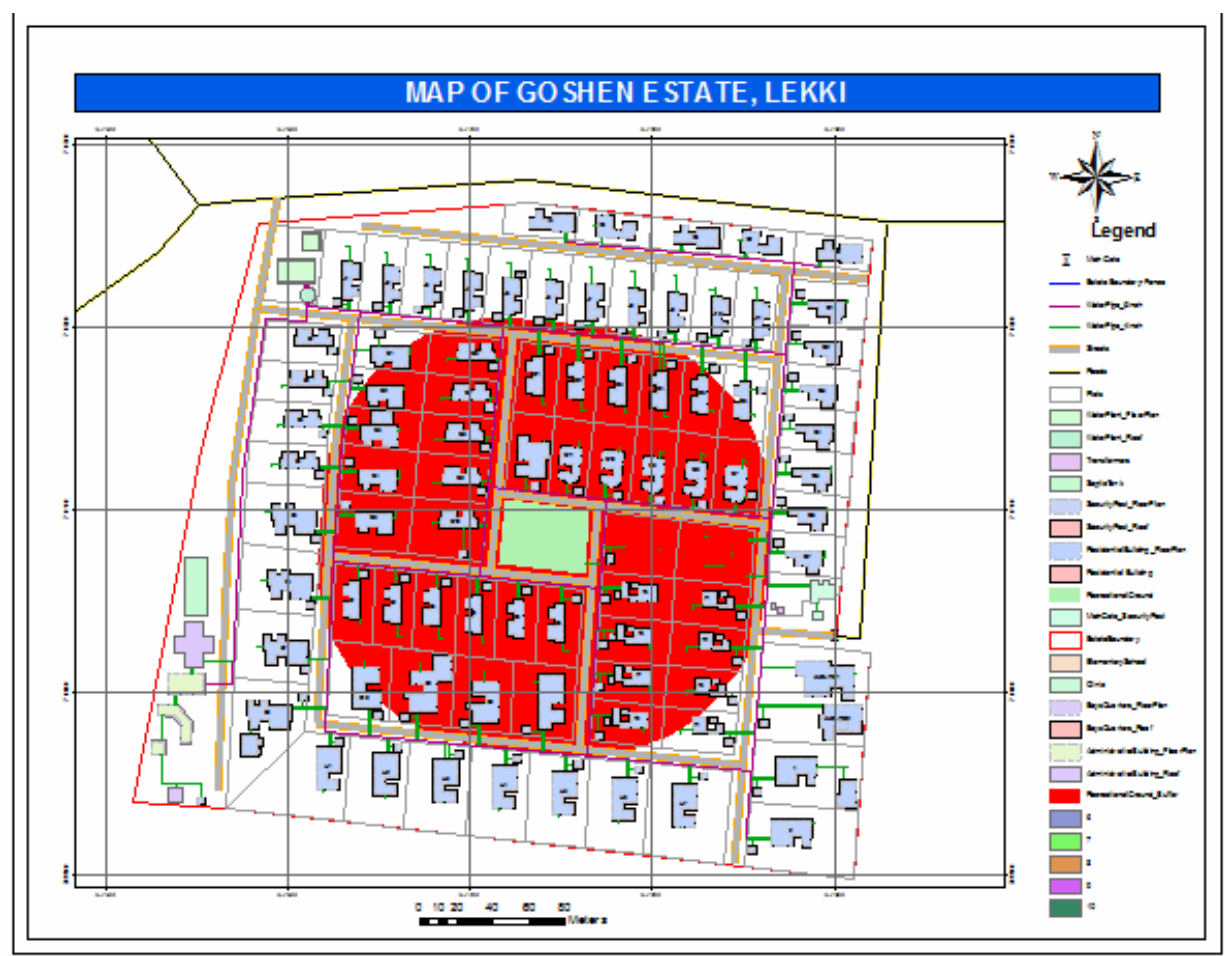

Fig 4.8 Buffer showing "Buildings within 100m of the recreation ground" (35 buildings)

Query 8 - Show the development on the Largest Plot in the Estate.

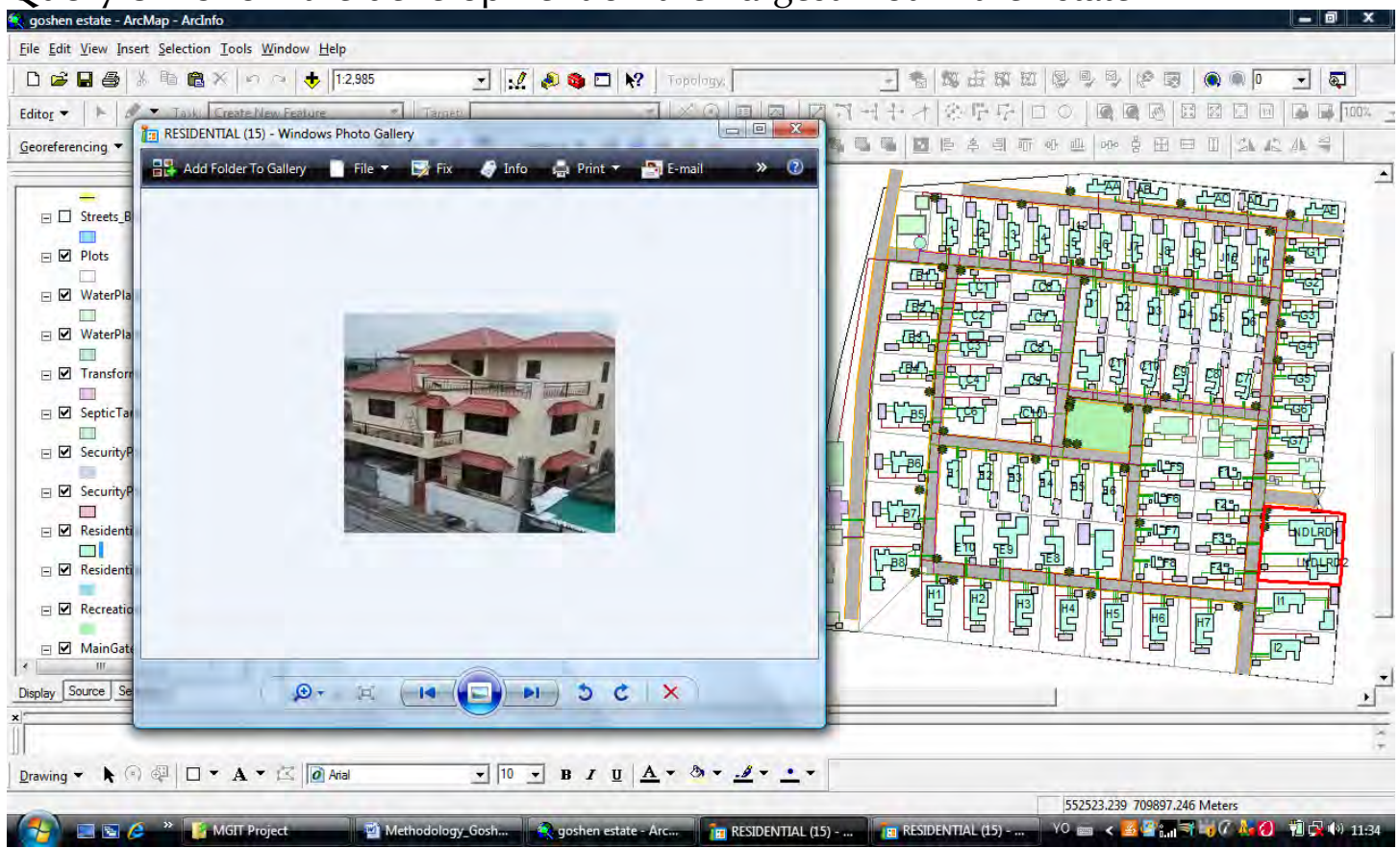

Fig 4.9 A query showing "hyperlinked picture of the development on the Largest Plot in the Estate.

\section{Analysis/Multifaceted Queries}

In the management of housing estates, some operational decisions are usually required to be made promptly. The inherent limitations of the analogue medium as currently being used in Goshen Beach Estate can be said to be time consuming. With a Digital Cadastral Mapping System (DCMS), decisions can easily be taken. Some of these complex analyses include: 
Some of the results of the queries are hereby further analyzed by performing complex queries such as:

1. Show all residential buildings that are 6 bedroom duplexes (Fig. 4.10).

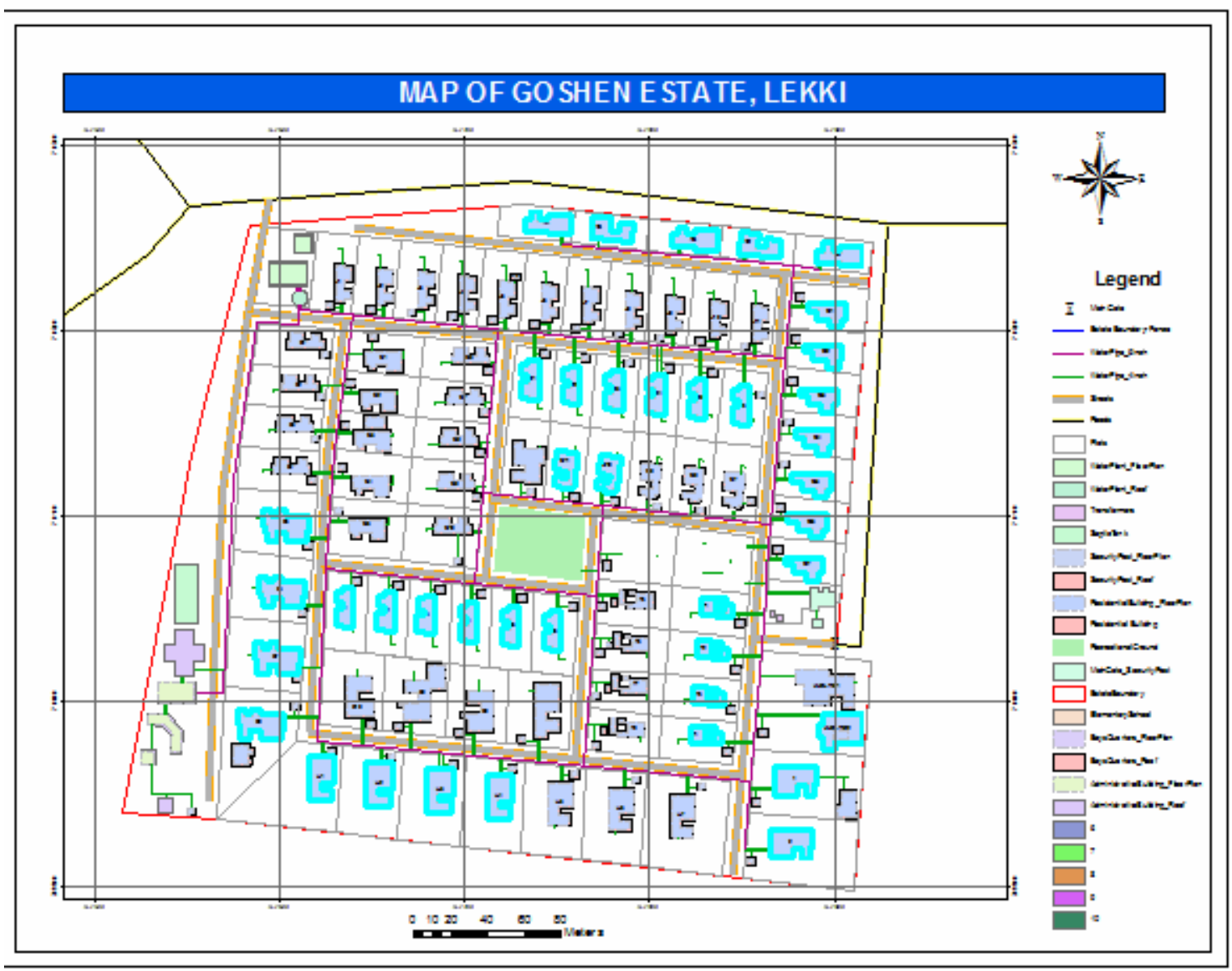

Fig 4.10 A query showing all "buildings that are six bedroom duplexes" (41 buildings)

This type of query acts as a basis for determining the spatial spread of this housing type and can therefore be used for analysis (Worboys \& Duckham, 2004). In classifying population density, building types can be relied upon to determine whether a neighbourhood is high density or low density, high income class or low income class. So a particular service provider may easily know whether this environment will be good for a particular kind of service that he provides, like DSTV, CCTV, and so on.

2. Select all plots whose area is greater than $1,000 \mathrm{~m}^{2}$ (Fig. 4.11). 


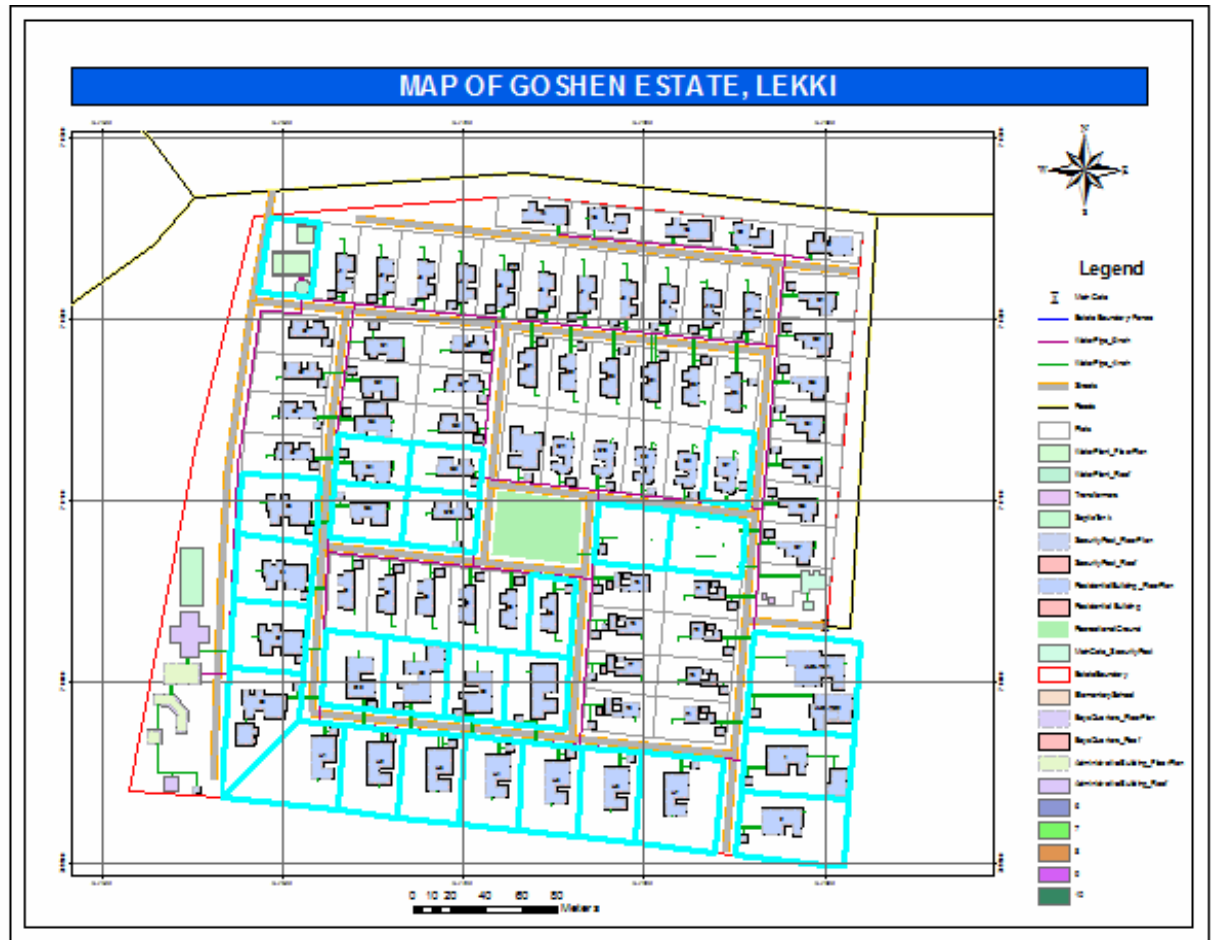

Fig 4.11 A query showing all "plots whose area is greater than 1,000m" (27 plots)

In determining charges for plots of land, area or size plays an important role, such charges include premium, capital development levy, ground rents, etc. this could help in rent or charges classification and consequently the determination of appropriate charges as relevant.

3. Which buildings have contravened road setback of 9m (Fig 4.12).

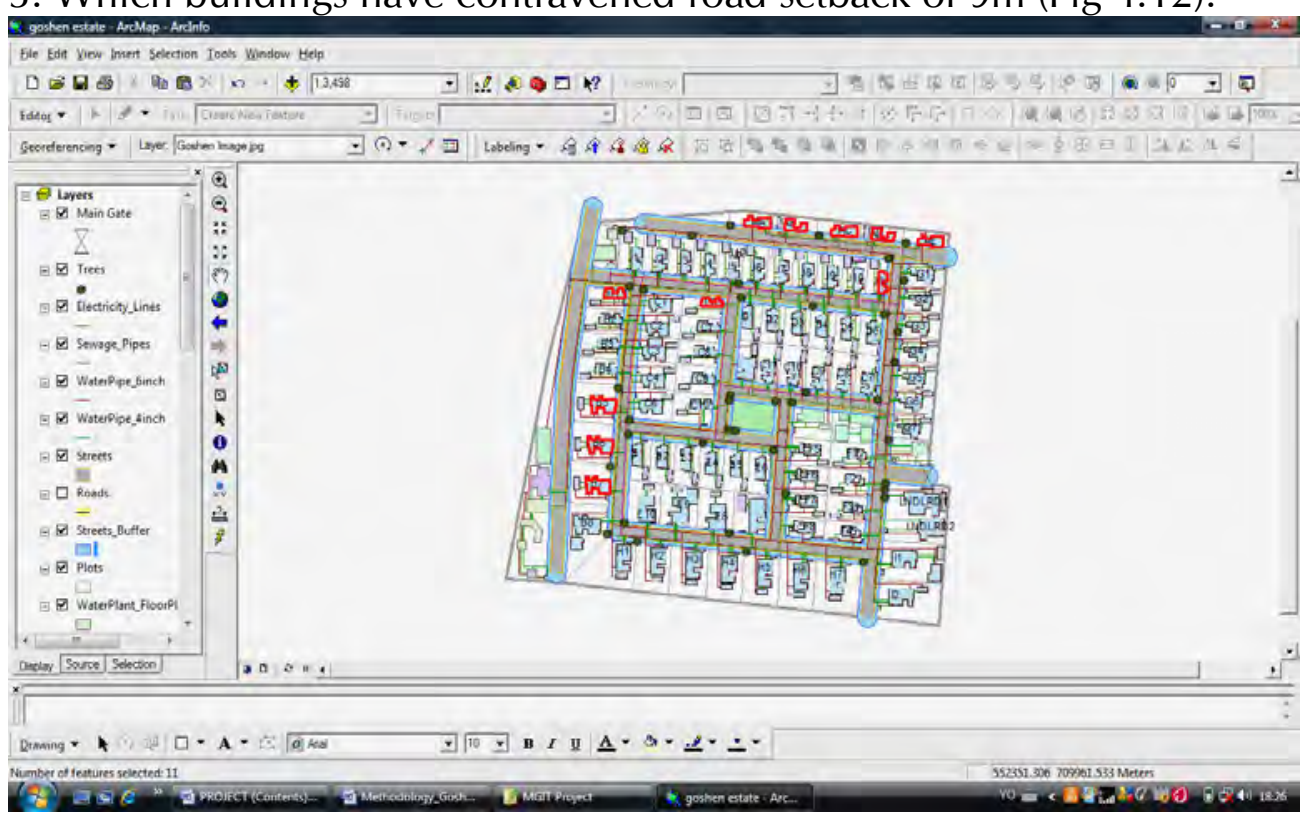

Fig 4.12 A query showing "Buildings contravening Street setback requirements" (11 buildings) 
Statutory organizations may be interested in knowing which buildings have contravened road setback requirements. In a place like Lagos for example, where a GIS is being developed for the whole state, the authorities in charge of building control can easily find out from their offices, the buildings that have contravened building setback requirement or that are on the right of way of drainage channels, for sanctions and/or removal.

\section{Quasi-Land Use Analysis}

The application was further used to do a simple Land use analysis to show graphically the various land uses and also to do a base comparison.

Land-use analysis is normally based on square metre areas, but this quasi-landuse analysis is based on number of buildings. It was used to determine land-use analysis and the created database was later classified into the following land-uses:

- Recreational

- Public Utility

- Educational

- Health Facility

- Main Residential

- Boys Quarters

- Administrative

- Commercial

A query was generated to show the land use status. The result is shown in Fig. 4.13

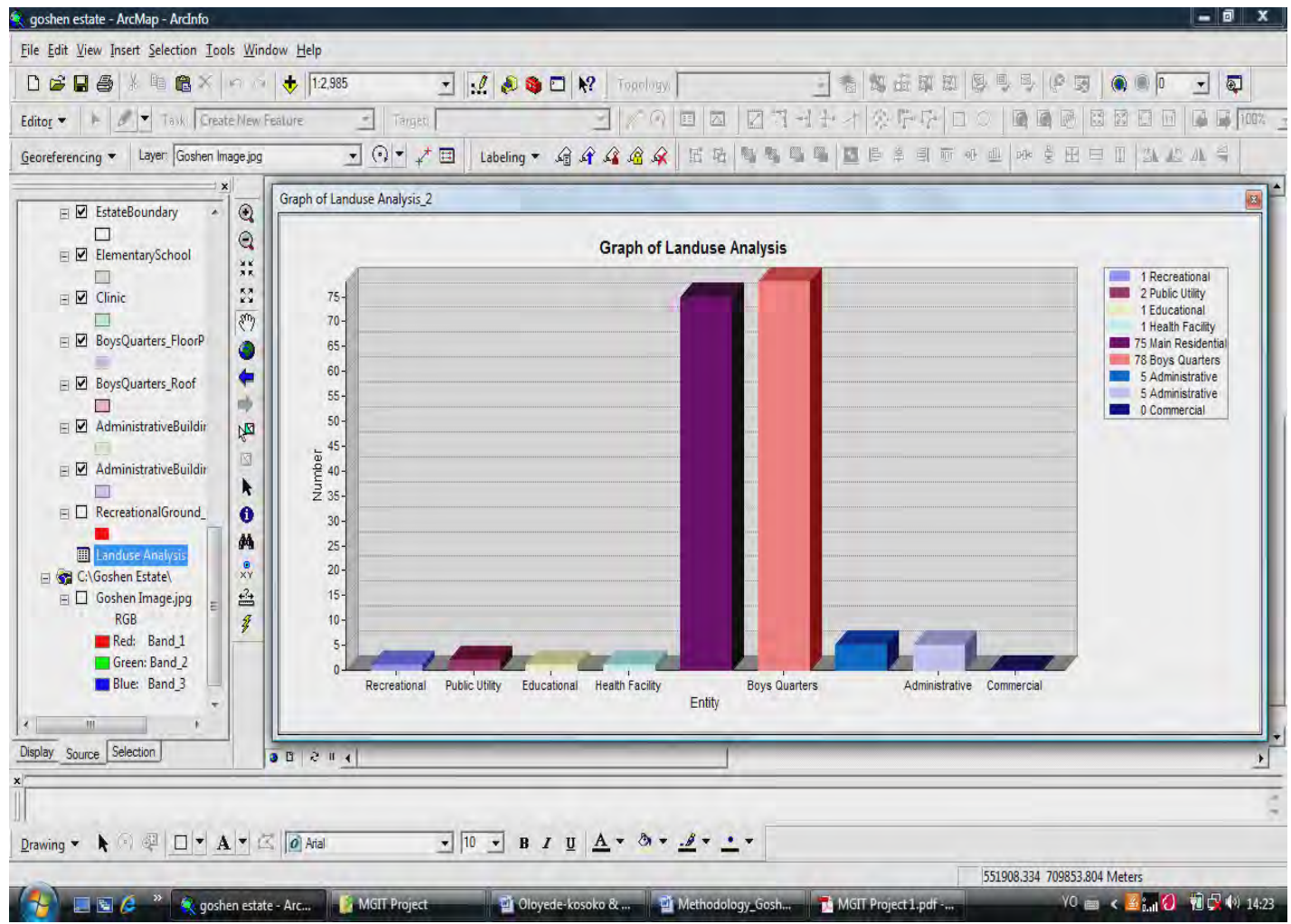

Fig 4.13 Graph showing the Land-use Pattern in Goshen Estate Beach. 


\section{Conclusion}

Land administration is a cumbersome process that requires several experts and nonprofessionals (e.g. land owners) and a lot of documentations. Analogue process is time consuming, labour intensive and expensive.

Introducing DCMS into land/property management at national to the private land developers and managers level is very crucial to development and sustaining the development. The spatial operations and analysis carried out in this study has brought out the fact that DCMS can be effectively and efficiently used in the management of landed properties.

This work has revealed that better results can be obtained by adopting DCMS than the traditional file processing approach in the management of land administration. It has become obvious that up to date information is made readily available by properly structured and regularly updated database as demonstrated by the use of DCMS. With a Cell-Based Digital Cadastral Mapping System (DCMS), from national to micro levels, there is an integration of cadastral map and their respective documents such as ownership, value, tax and right of ownership. DCMS will definitely assists in land use management, real-time land valuation and marketing and better resolutions of litigated boundaries (e.g. Goshen Beach Estate).

\section{References}

Adeoye, A. A. (2001), "Geographic Information System - Operations and Management", published by Information Management Consultants, Lagos

Ayeni, O. O., Kufoniyi, O. and Akinyede, J. O. (2003), "Towards a National Geospatial Information Policy for Nigeria" - Proceeding of the Technical Session of the $38^{\text {th }}$ Annual General Conference and Meeting of the Nigerian Institution of Surveyor, Lokoja, pp 21.

Buckley, D. J. (1997). "The GIS Primer, An Introduction to Geographic Information Systems". Innovative GIS Solutions, Inc. (http://www.innovativegis.com/basis/primer).

Burrough P. A (1991), "Principles of Geographic Information System", Oxford University Press

Eyong, I. E., Nwilo, P. C. and Orji, O. N. (2006), "Geoinformatics Technology Application to Housing

Estate Management in Nigeria". A Case Study of Gwarinpa II Estate, Abuja, Federal Capital Territory (FCT). A Presentation during GEOSON AGA 2006

Hardie, I.W. and Parks, P.J. (1994). "Land Use in a Region with Heterogeneous Land Quality: an Application of an Area Based Model".

http://www.arec.umd.edu/libcomp/Areclib/Publications/Working-Papers-PDF-files/9416.pdf.

Kufoniyi, O. (1998), "Basic Concepts in GIS". In Principle and Application of GIS (C.U. Ezeigbo Ed.). Series on Geoinformatics, published by the Department of Surveying and Geoinformatics at the University of Lagos. Panaf Press pp 1-15

Lawal, M. I. (1997), "Principles and Practice of Housing Management", Iko Books Press, lle Ife

Lucas, L. F. Janssen (2000)Ed, "Principles of Remote Sensing", published by International Institute for Aerospace Survey and Earth Services (ITC), Enschede, Netherlands. (ITC Educational Textbook series 2). 
Nwilo, P. C. (1998), "Data Acquisition by Ground Survey Methods", in Principles and Applications of GIS (C.U. Ezeigbo Ed) Series on Geoinformatics published by the Department of Surveying and Geoinformatics at the University of Lagos. p 105-122

Olaleye, J. B. (1998), "Concepts of the Multipurpose Cadastre", in Principles and Applications of GIS (C.U. Ezeigbo Ed) Series on Geoinformatics published by the Department of Surveying and Geoinformatics at the University of Lagos. pp 24-36

Oloyede-Kosoko, S.O.A. and Alagbe, A.O. (2005), "Property Management: A GIS Approach", A Presentation during GEOSON AGA 2005

Oluwi, J. B. (1994), "Introduction to Estate Management", Onward Press, Ibadan

Rolf A. Deby et al (2000), "Principles of Geographic Information System", published by International Institute for Aerospace Survey and Earth Services (ITC), Enschede, Netherlands. (ITC Educational Textbook series 1)

Uluocha Nna O. (2007), "Elements of Geographic Information Systems". Sam Iroanusi Publications, Lagos.

Worboys, M.F. and Duckham (2004), "GIS: A Computing Perspective" (2 ${ }^{\text {nd }}$ Edition). CRC Press, Amazon, UK 